\title{
Language Situation and Language Policy in Canada (In the Aspect of Multiculturalism)
}

\author{
Elena B. Grishaeva and Irina S. Dobriaeva* \\ Siberian Federal University \\ 79 Svobodny, Krasnoyarsk, 660041, Russia
}

Received 18.07.2015, received in revised form 27.09.2015, accepted 07.01.2016

\begin{abstract}
The article examines issues related to the typological arrangement and existence of the exoglossic, unbalanced language situation in Canada. Special attention is paid to the role of indigenous languages against the background of the language situation in the country. Canada's linguistic profile is described in the background of certain theoretical assumptions of multiculturalism and multilingualism. The article contains quantitative indicators related to the composition of the indigenous population speaking indigenous languages.
\end{abstract}

Keywords: multiculturalism, multilingualism, ethnicity, indigenous languages, indigenous population, language situation, bilingualism, assimilation, language policy.

DOI: 10.17516/1997-1370-2016-9-2-350-357.

Research area: culture studies.

Against the backdrop of homogenization of the world culture, scientists frequently capture the so-called "ethnic bursts", attempts of the representatives of various "minority" cultures to defend their identity. An integral method (and a tool) for self-identification and self-realization, as well as an important part of culture of an ethnic group or nation is its language.

Canada, the first country to officially recognize the policy of multiculturalism, is an example of a post-national (immigrant) state combining polyethnicity and multi nationality, where the indigenous peoples greatly succeeded in expanding their political rights and preservation of their cultural and linguistic diversity.
Unlike the USA that are inhabited by a large number of indigenous and immigrant groups, but aimed at levelling national and cultural differences and conversion to mononational and monocultural country, Canada has always tended toward a multicultural structure with a unified super nation. It is no coincidence that the national structure in Canada is compared with a mosaic, unlike the American model that once was called a "melting pot". A.I. Cherkasov characterizes the Canadian multiculturalism mechanism as follows: "one super ethnic nation (Canadians), two official languages (English and French) and many ethnic cultures." (Alpatov, 2000, p. 105)

(C) Siberian Federal University. All rights reserved

* Corresponding author E-mail address: e-grishaeva@mail.ru, elena.grishaeva2@mail.ru 
If the French and Anglo-Canadians are called the "founding nations" of Canada, the indigenous peoples are the "First Nations". The term "nation" in this case refers to "any community of people who see themselves as an ethnic, cultural and linguistic unity and oppose themselves to other communities around them." (Bell, 1980, p. 408)

In 1982, the Canadian Constitution identified three main groups of the indigenous population that are considered to be the "First Nations". These are the Indians $(60 \%$ of the indigenous population), the Metis (descendants of mixed marriages between Indians and Europeans) about $26 \%$, and the Eskimos (or the Inuit) $-4 \%$. (Bykhovets, 1988, p. 56)

Canada is the second country in the world in terms of the relative size of the indigenous population $(3.8 \%$ according to the population census in 2006). New Zealand takes the first place by this indicator (15\%), followed by the United States and Australia (2 \%). (Bykhovets, 1988, p. 56)

M. Kobo defines the "indigenous people" as indigenous communities, peoples and nations that preserve historical continuity with societies that existed prior to the invasion of conquerors and introduction of the colonial system and developed on their own territories considering themselves distinct from other strata of society prevailing on these territories at the present time, or in parts of these territories, as well as not being dominant, they want to preserve, develop and pass their ancestral territory and their originality to future generations as a basis for their existence as a people in accordance with their own cultural characteristics, social institutions and legal systems. (cit. ex Crystal, 2007, p. 34)

One of the key issues in the field of rights of the indigenous peoples is their inherent distinctiveness. Native language and its preservation is one of the most important elements of identity of the indigenous people. With the loss of all other distinguishing characteristics, the language features usually allow the indigenous peoples to save the status quo in relation to other parts of population of the country. Therefore, an important role in the practice of the majority of states is taken by the legal regulation of language relations.

According to some researchers, the indigenous peoples can be attributed to national and ethnic minorities, but unlike the minorities that can be "embedded" in the environment of the dominant part of population, the indigenous peoples are ethnic communities compactly residing in the ancestral territory. For example, in Canada, there are about 2366 reservation areas that are home to 630 registered Indian communities and the north of the country is inhabited by the Inuit. (Bykhovets, 1988, p. 58)

There are many different languages of the indigenous peoples. Currently in Canada, there are about 50 indigenous languages belonging to 11 major Indian language groups. The three largest language groups - Algonquian, Inuktitut and Athabaskan - represent almost $94 \%$ of the indigenous population.

Canada is characterized by special "sensitivity" to the issues of coexistence of various languages in the state, which is caused by long coexistence of the two world languages, the official languages of Canada: English and French. The issues of their relation were at the forefront of Canadian politics throughout the history of development of the Canadian society creating a unique linguistic situation.

The term "language situation" refers to a set of linguistic formations providing service for a continuum of communication in a certain ethnic community, or in an administrative-territorial association. The concept of "language situation" can mean only an organized set of languages, the languages are interlinked not only because of a 
close contact between the linguistic communities that make up the population of a political and territorial union, but also because of their attitude to the continuum of communication of the community and to each other. (Dorey, 2007, p.101)

By quantitative features today's linguistic situation in Canada can be described as exoglossic, unbalanced, multipolar (with two dominant idioms). By qualitative features the Canadian version of the English language in a given language situation is a language-macrointermediary, the French language can be attributed to the regional languages, the main spread region of which is the Canadian province of Quebec; the immigrant and indigenous languages belong to the category of local or "home languages".

The official status of the indigenous languages is quite uncertain. In accordance with the international law and the UN conventions, the indigenous peoples have the right to use their own language.

However, the lack of an equal status with the official languages of the state naturally led to a reduction of the functional range of the indigenous languages that at this time can be described as languages with limited functions. In a communicative continuum of the Canadian community these languages serve as languages of everyday communication.

According to V.M. Alpatov, it is a less favourable option than when a minority language serves as a regional language, but more favourable than its complete disappearance. (Foley, 2008, p. 221)

The fact that the mother language of a person is one of the local languages does not mean that a person speaks it daily. The percentage of people speaking the local language constantly or using it as a home language is relatively low across Canada: $60 \%$ (82.6 among the Eskimos and $89.4 \%$ among the Innu). In Quebec this figure is much higher (89.3\%), while among the Cree, the Atikamekw and the Eskimos it exceeds $90 \%$. (Grishaeva, 2006, p. 139)

Multiculturalism of the Canadian society and national multilingualism is fulfilled in the form of individual (forced) bilingualism in combination with diglossia (recognition of a higher status of language - macrointermediary) for the part of the indigenous population (as well as the Francophones and immigrants) and monolingualism of a certain part of the population within linguistic communities (about $8 \%$ of the indigenous population of Canada speak only their native language). Monolingualism of the indigenous population may also be a consequence of assimilation: it implies their refusal to use their native language, in particular, in case of the highstatus Indians who left reservation areas (about $60 \%$ of aboriginal people in Canada live outside the reservation areas), and only $12 \%$ of them can communicate in their native language, while more than $50 \%$ of aboriginal people living in reservation areas can speak their native language. In this case, there is transition to the official language - macrointermediary.

Without a doubt, the fate of the minority and indigenous languages to a large extent depends on the language policy pursued by the state. At the moment, having abandoned the policy of assimilation of the indigenous population carried out from the time of colonization, the Canadian government has been taking measures for the legislative and financial support for the indigenous peoples and their languages. So, in 1983, the National Assembly adopted 15 laws regulating relations with the indigenous peoples, and some laws are devoted to language problems. These laws recognize the right of the indigenous peoples in the country to use their mother language, to have facilities that meet their needs, and their right to be protected by the state. (Guboglo, 1973, p. 180) 
In an effort to save the still-functioning indigenous languages, the researchers propose a policy to help aboriginal people to maintain their linguistic communication in their native language ensuring the opportunity to pass their mother language to the fullest extent from generation to generation.

Canada's language policy pursued in relation to the indigenous languages is based on five basic principles:

1) Normal functioning of the language in family communication;

2) Use of language in a public life of the community;

3) Language training in schools;

4) Expansion of the use of language by involving new areas of communication;

5) Ensuring the existence of languages by means of laws and the Constitution (Guboglo, 1973, p. 181).

Although the referendum held in 1992 resulted in that self-government was denied to the indigenous peoples of Canada, in April 1999, Canada acquired a new territory - Nunavut, $85 \%$ of which is inhabited by the Inuit. As the newest partner in the Canadian Federation, Nunavut is the result of significant changes in the Canadian policy towards the indigenous population representing the right of the Aboriginal population to self-determination and self-government, which demonstrates the new principles of the Canadian nation-building. In general, the preservation of the cultural heritage of all the indigenous peoples of Canada is protected by law.

Recent political initiatives, such as the Report of the Commission of Nunavik that suggests creating the regional government of the Eskimos in the Arctic regions of Quebec, and the principal union of the Innu Mamuitin (Quebec), give the indigenous population the full legal independence in matters of language and culture, which also gives them the power in such areas as education and working language. Currently, in the registry of the Ministry of Indian Affairs and Northern Development there are 55 national indigenous organizations (including international ones) operating in the areas important to the Aboriginal peoples. (Bykhovets, 1988, p. 65-69]

The most optimal model in the process of language interaction in the multiethnic and multicultural spaces is a bilingual and, in some cases, multilingual model reflecting the model of multiculturalism that is formally adopted in such countries as Canada, Australia, the USA and Sweden. This model implies that different ethnic and social groups preserve their identity, cultural and linguistic traditions. Solving linguistic problems of multinational states should be carried out taking into account the status of multilingual groups in a multilingual environment, as well as the forms of their social interaction. (Kirkpatrick, 2007, p. 246)

Canada is a unique example of maintaining a balance between the preservation of the integrity of a multicultural nation and respect for the "minority" languages, languages of ethnic groups and communities.

The experience of the national language development in Canada showing the possible solutions to national problems in a multinational country undoubtedly enriches the world language legislation. In 1971, the Multiculturalism Act was adopted by the Government of Canada recognizing the fundamental principle implying that multiculturalism "reflects the cultural and racial diversity of the Canadian society and acknowledges the freedom of all of its members to preserve, multiply and share the cultural heritage... The Act also acknowledges that multiculturalism is a fundamental principle of the Canadian heritage and identity." (Klokov, 2005, p. 15) After the adoption of the Act the Government of Canada contributed to the further recognition of diverse cultures of the Canadian 
society. It should be noted that this Act was a part of the legislative matrix that informed and defined it at the same time.

Other legal documents were the Canadian Charter of Rights and Freedom and the Canadian Human Rights Act that guaranteed fundamental freedoms and equal democratic rights for all citizens of the country. According to these statutes, any racial and religious discrimination against members of the Canadian society was prohibited. In 1995, the Canadian Government adopted the Employment Equity Act providing that each employee requires special measures in accordance with their national and ethnic features.

In the context of the ongoing crisis of the multiculturalism ideas it is expedient to note that multiculturalism has taken shape in the depths of the contradictory political trends that influence the actions of politicians at different levels and public discussions on racial, ethnic and religious differences. At present, the concept of multiculturalism puts in question a certain way of thinking and a certain political position. It is interesting to note that social theory, political science and cultural studies were the first disciplines that have shown interest in these differences.

Among contemporary theorists of multiculturalism a position of W. Kymlicka is especially interesting. His point of view was expressed in his book "Liberalism, Community and Culture" (1989). In 1995, he introduced a term of "multicultural citizenship". According to the scientist, such countries as the USA, Australia and Canada are not national, but multinational states. The composition of each of them includes several nations, such as the Apache and the Quebecois. At this, the dominant nations contributed to taking the status of nation away from the minority indigenous groups. By nations W. Kymlicka means a multiethnic, dominant nation in the United States and Canada that has historically absorbed flows of migrants from around the world and has grown into a nation that still remains open. In other words, W. Kymlicka identifies nation with "public culture", the main elements of which are language, social structures, norms and attitudes, institutions, traditions and habits. (Kozhemiakina, 2003, p. 18)

At the same time, W. Kymlicka claims that the post-immigrant groups cannot form a public culture. They, by definition, have left their culture in their country and can no longer create a new one because they do not have the political, economic power, and are not related to other social institutions that underlie the public culture (Klokov, 2005, p. 30). Continuing the thought, the scientist says that "if the immigrants voluntarily leave their native country in search for a better life, they must integrate into the host country that, in turn, is obliged to accept all members of the immigrant community and their descendants as citizens with full rights." (Klokov, 2005, p. 30) According to W. Kymlicka, integration does not mean assimilation when immigrants are not allowed to retain their cultural identity. Immigrants and subsequent generations, in his opinion, can preserve not only their native language and culture, but what is most important - they can have a dual identity, for example, be referred to as Americans of Irish origin or British of Indian origin (Kymlicka, 1995, p. 96-97]. Thus, he proposes "multicultural citizenship" as the key argument in favour of the political adaptation of minority populations. Since the immigrants should be integrated into the host group, this "pill" may be sweetened by the guarantee of multiethnic rights.

For obvious reasons, the theory of W. Kymlicka is full of contradictions and inconsistencies and, therefore, can serve as a starting point for a wide-ranging debate on the subject of multiculturalism. Recent events 
marked with the storm of European boundaries by the new immigration flows from the Arabic countries only confirm that there is a need for an adequate understanding of the phenomenon of multiculturalism in today's world that is devoid of an anti-immigration prejudice considering it at the conceptual level in conjunction with the phenomena of ethnicity and religion. Against this backdrop, the central problem is the "context of choice", since the Western political theory is based on the liberal idea of search for individual autonomy.

\section{References}

Alpatov, V.M. (2000) 150 iazykov i politika [150 languages and politics]. Moscow, Kraft + IV RAN, 224 p.

Bell, R. (1980) Sotsiolingvistika [Sociolinguistics]. Moscow, Mezhdunarodnye otnosheniia. 317 p.

Bykhovets, N.N. (1988) Leksicheskie osobennosti angliiskogo iazyka Kanady [Lexical features of the English language in Canada]. Kiev, Naukova dumka, $150 \mathrm{p}$.

Crystal, D. (2007) English as a global language. Cambridge University Press, 212 p.

Dorey, L.-J. (2007) Tekushchee sostoianie korennykh iazykov v Kanade i Kvebeke [Current state of the indigenous languages in Canada and Quebec]. In Iazykovaia politika v sovremennom mire [Language policy in the modern world]. Saint-Petersburg, Zlatoust, 137-142.

Foley, W. Anthropological linguistics. Blackwell Publishing, 2008. 495 p.

Grishaeva, E.B. (2006) Tipologiia iazykovykh politik i iazykovogo planirovaniia vpolietnicheskom i multikul'turnom prostranstve (funktsional'nyi aspekt) [Typology of language policies and language planning in a multiethnic and multicultural space (functional aspect)]. Krasnoyarsk, 276 p.

Guboglo, M.N. (1973) Etnolingvisticheskie kontakty i dvuiazychie [Ethnolinguistic contacts and bilingualism]. In Sotsial'noe i natsional'noe (Opyt etnosotsiologicheskikh issledovanii) [The social and the national (Experience of ethno-sociological studies)]. Moscow, Nauka.

Kirkpatrick, A. (2007) World Englishes. Cambridge University Press. 257 p.

Klokov, V.T. (2005) Frantsuzskii iazyk v Severnoi Amerike [French language in North America]. Saratov: Izdatel'stvo Saratovskogo Universiteta, 400 p.

Kozhemiakina, V.A.(2003)Iazykovaia situatsiia i iazykovaia politika v Kanade[Language situation and language policy in Canada]. In Reshenie natsional'no-iazykovykh voprosov v sovremennom mire [Solving national-language issues in the modern world]. Saint-Petersburg, Zlatoust, 170-188.

Kymlicka, W. (1995) Multicultural Citizenship. Oxford, Oxford University Press.

Kymlicka, W. (2001) Western Political Theory and Ethnic Relations in Eastern Europe. W. Kymlicka and M. Opalski (eds) in Can Liberal Pluralism be Exported? New York, Oxford University Press, 13-105.

(2005) Languages in a globalizing world. Cambridge University Press. 345 p.

Maksimova, D.D. (2010) Korennye narody Kanady: evoliutsiia otnoshenii s gosudarstvom [Indigenous people in Canada: evolution of relations with the state]. In SShA. Kanada. Ekonomikapolitika-kul'tura [USA. Canada. Economics-politics-culture] 12, 55-71.

Modood, T. (2013) Multiculturalism. Second edition. Polity Press. 243 p.

Neshchimenko, G.P. (2003) Iazykovaia situatsiia v slavianskikh stranakh: Opyt opisaniia. Analiz kontseptsii [Language situation in the Slavic countries: Description experience. Analysis of concepts]. Moscow, Nauka, 279 p. 
Nikol'skii, L.B. (1967) Izuchenie iazykovoi situatsii kak prikladnaia iazykovaia distsiplina (K postanovke voprosa) [Study of language situation as applied language discipline (statement of question)]. In Istoriko-filologicheskie issledovaniia [Historical-philological studies], 125127.

Pereosmyslenie Kanady: kross-kul'turnye razmyshleniia o kanadskom obshchestve [Representations of Canada: Cross-cultural Reflections of Canadian Society]. VolSU, Centre of American Studies, Pennsylvania Association of Canadian Studies, Volgograd, Izd-vo VolGU, 270 p.

Peshperova, I.Iu. (2008) Zashchita korennykh narodov v ramkakh organizatsii ob"edinennykh natsii [Protection of indigenous peoples in the framework of the United Nations]. Saint-Peterburg, SZAGS. 66 p.

Ponto, M. (2007) Iazykovye politiki v multikul'turnom prostranstve. Iazykovaia adaptatsiia immigrantov. Sluchai Kanady [Language policies in a multicultural space. Language adaptation of immigrants. The case of Canada]. In Russkii iazyk kak gosudarstvennyi iazyk Rossiiskoi Federatsii $\mathrm{i}$ iazykovaia politika $\mathrm{v}$ sovremennom mire [Russian language as a state language of the Russian Federation and language policy in the modern world]. Saint-Petersburg, Zlatoust, 143-149.

Saarinen, L., Rybkina, E. (2001) Kanada [Canada]. Country Study. Saint-Petersburg: KARO, 238 p.

Schweitzer, A.D., Nikol'skii, L.B. (1978) Vvedenie v sotsiolingvistiku [Introduction into sociolinguistics]. Moscow, Vysshaia shkola, 215 p.

Sokolovskii, S.V. (2007) Pravovoi status i identichnost' korennykh narodov [Legal status and identity of the indigenous peoples]. In Rasy i narody: sovremennye etnicheskie i rasovye problemy [Races and nations: modern ethnic and racial issues], 33, 11-57.

Stepanov, G.V. (1976) Tipologiia iazykovykh sostoianii i situatsii v stranakh romanskoi rechi [Typology of language states and situations in countries of Romance speech], Moscow, Nauka, $224 \mathrm{p}$. 


\section{Языковая ситуация и языковая политика Канады (В аспекте мультикультурализма)}

Е.Б. Гришаева, И.С. Добряева

Сибирский федеральный университет Россия, 660041, Красноярск, пр. Свободный, 79

Статья рассматривает вопросы, связанные с типологическим оформлением и существованием в Канаде экзоглоссной, неравновесной языковой ситуации. Отдельное внимание уделено роли автохтонных языков на фоне мозаично представленной в стране языковой ситуации. Лингвистический профиль Канады описан на фоне отдельных теоретических положений мультикультурализма и мультилингвизма. В статье содержатся количественные показатели, имеющие отношение к составу коренного населения, говорящего на автохтонных языках.

Ключевые слова: мультикультурализм, мультилингвизм, этничность, автохтонные языки, коренное население, языковая ситуация, билингвизм, ассимиляция, языковая политика.

Научная специальность: 24.00.00 - культурология. 